Transactions of the Karelian Research Centre of the Russian Academy of Sciences

No. 2. 2020. P. 5-17

DOI: $10.17076 /$ geo1180
Труды Карельского научного центра РАН

№ 2. 2020. С. 5-17

УДК $551.24: 551.71(540)$

\title{
BUNDELKHAND, ARAVALLI AND DHARWAR CRATONS (INDIAN SHIELD): COMPARISON OF ARCHEAN CRUSTAL EVOLUTION AND LOCATION IN THE KENORLAND SUPERCONTINENT STRUCTURE
}

\author{
A. I. Slabunov', V. K. Singh ${ }^{2}$ \\ ${ }^{1}$ Institute of Geology, Karelian Research Centre, RAS, Petrozavodsk, Russia \\ ${ }^{2}$ Department of Geology, Bundelkhand University, Jhansi, India
}

\begin{abstract}
Comparison of the Meso-Neoarchean crustal evolution of the Bundelkhand, Aravalli, Western and Eastern Dharwar Cratons shows that geodynamic mechanisms, similar to modern plate-tectonic and mantle-plume, were active in that period. The Mesoarchean crustal evolution of the Bundelkhand Craton is considerably different from that of other cratons discussed here in that it comprises subduction-accretion processes, while in other cratons plume processes were more active in this period. In the Neoarchean $(2.7-2.5 \mathrm{Ga})$, all the cratons display subduction-accretion processes. Each of the cratons displays its own crust formation pattern. It seems that in Mesoarchean time the Bundelkhand, Aravalli, Western and Eastern Dharwar Cratons were parts of the Kenorland Supercontinent, rather than one block.
\end{abstract}

Keywords: Archean; crustal evolution; geodynamics; Indian Shield; Bundelkhand Craton; Western Dharwar Craton; Eastern Dharwar Craton; Aravalli Craton.

\section{А. И. СЛабУНОВ, В. К. СИНГХ. БУНДЕЛКХАНДСКИЙ, АРАВАЛЛИ И ДХАРВАРСКИЙ КРАТОНЫ ИНДИЙСКОГО ЩИТА: СРАВНИТЕЛЬНЫЙ АНАЛИЗ ИСТОРИИ РАЗВИТИЯ ЗЕМНОЙ КОРЫ В АРХЕЕ И ПОЛОЖЕНИЕ В СТРУКТУРЕ СУПЕРКОНТИНЕНТА КЕНОРЛЕНД}

Сравнительный анализ истории развития земной коры Бунделкхандского, Аравалли и Дхарварского (Западного и Восточного) кратонов Индийского щита в мезо-неоархее показывает, что геодинамические процессы, в ходе которых она формировалась, были сходны с современными плитно-тектоническими и плюмовыми. Каждый из кратонов имеет специфические особенности развития, но в большей степени выделяется Бунделкхандский. В мезоархее новая континентальная кора формировалась здесь в ходе субдукционно-аккреционных процессов, в то время как на других кратонах отмечается влияние лишь мантийных плюмов. В неоархее на всех рассматриваемых кратонах отмечены проявления субдукционных и аккреционных геодинамических процессов. Рассматриваемые кратоны в мезо-неоархее входили в состав суперконтинента Кенорленд в качестве самостоятельных фрагментов и не образовывали единый блок.

Ключевые слова: архей; эволюция земной коры; геодинамика; Индийский щит; Бунделкхандский кратон; кратон Западный Дхарвар; кратон Восточный Дхарвар; кратон Аравалли. 


\section{Introduction}

Archean rocks in the Indian Shield are exposed in the Bundelkhand and Aravalli Cratons to the north and in the Dharwar (Western and Eastern), Singhbum and Bastar Cratons to the south, respectively, as far as the E-W trending Central Indian tectonic zone (Fig. 1) [Naqvi and Rogers, 1987; Ramakrishnan and Vaidyanadhan, 2010; Roy and Purohit, 2018]. The Western and Eastern Dharwar Cratons are wellknown in the world [Radhakrishna and Ramakrishnan, 1990; Chadwick et al., 2000; Ramakrishnan and Vaidyanadhan, 2010; Jayananda et al., 2013, 2015] and can be used as standard geological associations. Tonalite-trondhjemite-granodiorite (TTG), supracrustal (greenstone and schist), granitoids and other typical Archean complexes were identified in the Bundelkhand and Aravalli Cratons in the recent studies [Singh and Slabunov, 2013, 2015a, b, 2016; Kaur et al., 2014, 2019; Verma et al., 2016; Saha et al., 2016; Slabunov et al., 2017a; Slabunov and Singh, 2019a; Singh et al., 2019a, b, 2020; Nasipuri et al., 2019]. The aim of the present paper is to resume earlier works [Slabunov, 2013; Slabunov and Singh, 2018, 2019a, b] through comparative analysis of the Archean crustal evolution of the Bundelkhand Craton and other structures of this type globally.

\section{Geology and crustal evolution of the Bundelkhand Craton}

The Bundelkhand Craton (Fig. 2, a) consists of Archean TTG rocks, granitoids (K-granites, diorites, sanukitoids), greenstone complexes, maficultramafic layered intrusion [Singh and Slabunov, 2015a, 2016; Verma et al., 2016; Joshi et al., 2017;

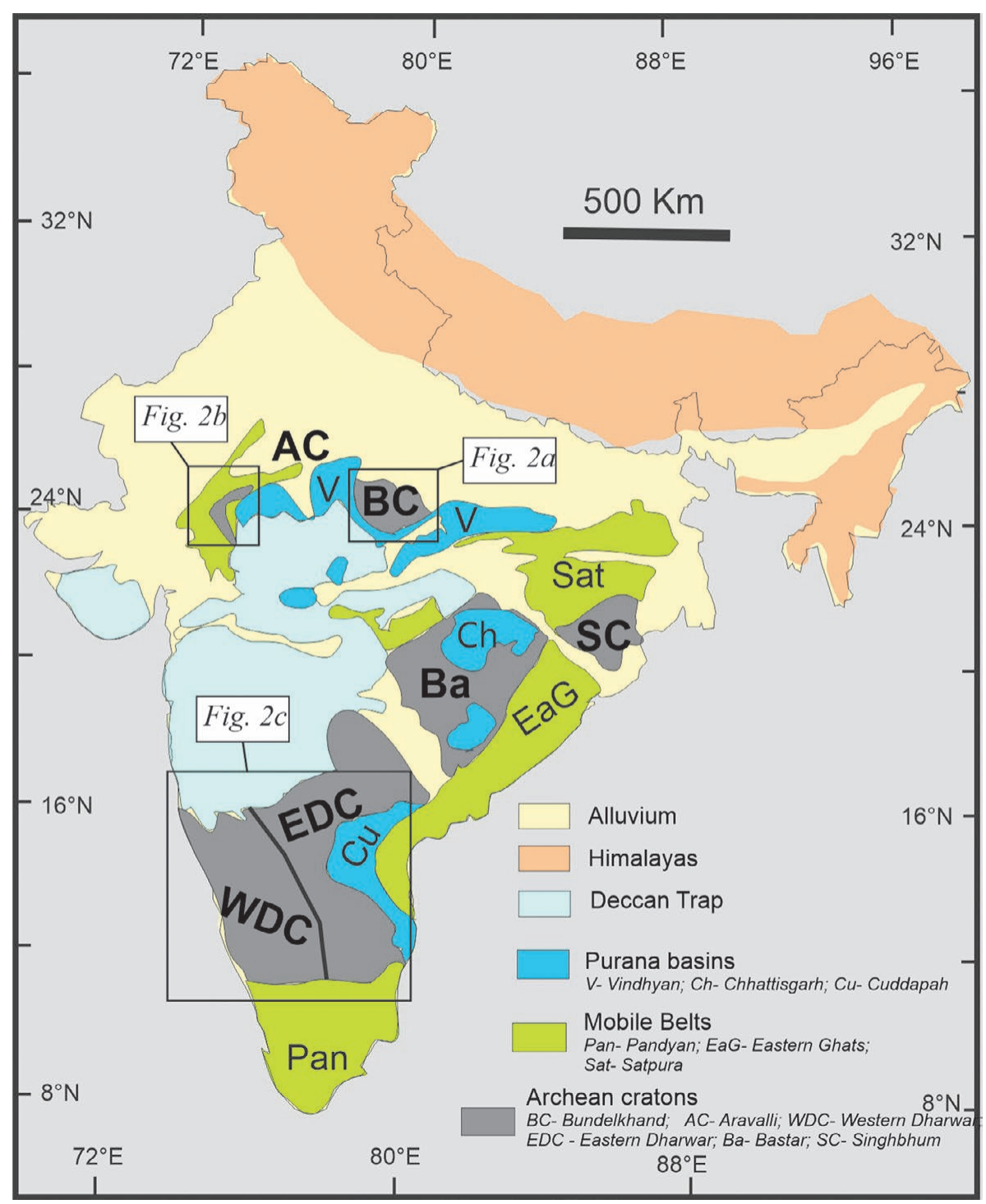

Fig. 1. Main tectonic division of the Indian Shield [Ramakrishnan and Vaidyanadhan, 2010] and locations of the Bundelkhand (BC), Aravalli (AC), Western Dharwar (WDC) and Eastern Dharwar (EDC) Cratons 

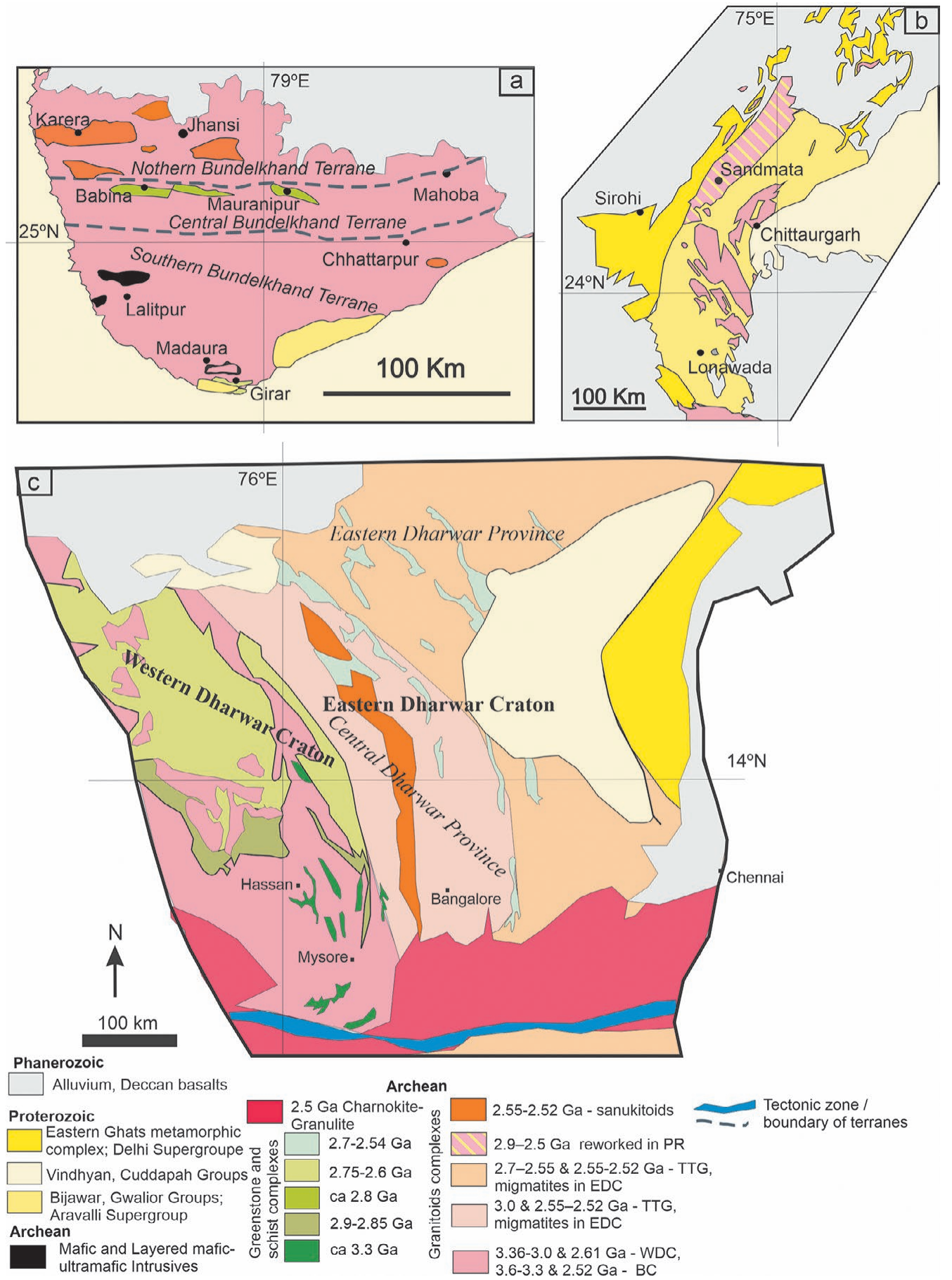

Fig. 2. Geological maps of the (a) Bundelkhand Craton [after: Mondal et al., 2002; Singh and Slabunov, 2015a, 2016; Saha et al., 2016; Slabunov and Singh, 2019b; Singh et al., 2020]; (b) Aravalli Craton [after: Roy and Purohit, 2018; Kaur et al., 2019]; (c) Western Dharwar and Eastern Dharwar Cratons [after: Chardon et al., 2008; Jayananda et al., 2013, 2015]

Slabunov et al., 2018a, b; Slabunov and Singh, 2019a; Singh et al., 2019a, b, 2020 and references therein], Paleoproterozoic mafic dykes and huge quartz veins [Basu, 1986; Singh et al., 2019c; Slabunov et al., 2017b]. The granite-greenstone complex has formed a basement for the deposition of Paleoproterozoic sedimentary rocks (the Gwali- or basin in the northwestern and the Bijawar basin in the southern to southeastern part of the craton). NW-SE-trending mafic dyke swarms (dolerites and gabbroic rocks) cross-cut the craton. These polychronous swarms consist of bodies of three age groups: ca. 1.98, 1.8 and $1.0 \mathrm{Ga}$ [Basu, 1986; Pradhan et al., 2012]. Giant NE-SW-trending hy- 
drothermal quartz veins also cut through most part of the cratonic rocks and penetrate into the sediments resting at the base of the Bijawar and Gwalior rift-related basins rimming it on the north and south [Pati et al., 2007; Slabunov et al., 2017b; Slabunov and Singh, 2019c; Singh et al., 2019c]. Mesoto Neoproterozoic (Vindhyan Supergroup) rocks were also deposited to the southeastern, southern, southwestern and western parts of the craton (Figs. 1 and 2, a) [Basu, 1986; Ramakrishnan and Vaidyanadhan, 2010].

The oldest TTG complex in the craton are dated at 3.6-3.2 Ga [Mondal et al., 2002; Kaur et al., 2014, 2016; Saha et al., 2016]. The TTG complex generally strike ESE-WNW. These granitoids are associated with amphibolites. In the Babina greenstone belt the amphibolites are interpreted as the earliest mafic-ultramafic association of the Central Bundelkhand greenstone complex and its Sm-Nd isochron age is estimated at $3435 \pm 161 \mathrm{Ma}$ [Singh et al., 2019a]; thus it is similar in age to early TTG.

The authors and coworkers have identified the Central and the Southern Bundelkhand supracrustal (greenstone and schist) complexes in the craton [Singh and Slabunov, 2013, 2015a, b, 2016; Slabunov et al., 2017a; Slabunov and Singh, 2019a; Singh et al., 2020]. The Central Bundelkhand Greenstone Complex forms the Babina and Mauranipur Greenstone belts (GBs) and generally shows an E-W linear trend (Fig. 2, a). This complex consists of an early (Mesoarchean) assemblage, which contains basic-ultrabasic, felsic volcanic (2810 $\pm 13 \mathrm{Ma}$ ) and BIF rocks; and a late (Neoarchean - ca. $2.54 \mathrm{Ga}$ ) assemblage composed of felsic volcanic rocks. The Babina GB contains three stratotectonic associations: 1) a maficultramafic association (with preserved small lensshaped schistose-structured bodies); 2) an iron formation association (BIF); and 3) a dacite-rhyolite association (felsic volcanics). The first two associations constitute an early assemblage and the third association is a late assemblage. The boundaries between the assemblages extend as mélanges along the tectonic contact.

The Central Bundelkhand greenstone belt displays a polymetamorphic evolution pattern. Paleoarchean amphibolite/granulite-facies, Mesoarchean eclogite-facies metamorphic events have been revealed locally [Saha et al., 2011; Nasipuri et al., 2019], while Neoarchean amphibolite-facies metamorphism (at least $586-679^{\circ} \mathrm{C}$ and $6.7-7.2 \mathrm{kbar}$ ) is more common [Sibilev et al., 2019]. These metamorphic stages are possibly associated with metasomatic events in the craton. The latest metamorphism in the cratonic rocks took place locally under prehnite-pumpellyite-facies conditions and seems to have been provoked by Paleoproterozoic (ca 1.9-1.8 Ga) rifting [Slabunov and Singh, 2019c].

At the northern and southern margins of the Central Bundelkhand Greenstone Complex, a series of Neoarchean (2.54-2.56 Ga) sanukitoid massifs was revealed [Joshi et al., 2017; Singh et al., 2019b, 2020]. Late- to post-kinematic Neoarchean (2.53-2.51 Ga) granites are the most common in the craton [Verma et al., 2016 and references therein]. They were formed during accretion after partial melting of TTG.

The Southern Bundelkhand schist/metasedimentary complex has formed the Girar belt (Fig. 2, a). This schist belt consists of two group of rocks [Singh and Slabunov, 2016] i. e. (i) quartzite, (ii) BIFs, and traces of dolomitic marble with chlorite schist lenses near the quartzite/BIF boundary. U-Pb detrital zircon data from quartzite rocks of the Girar belt give an older age of $3.43 \mathrm{Ga}$ and a younger age of $3.25 \mathrm{Ga}$, suggesting that $3.25 \mathrm{Ga}$ is perhaps the minimum age of provenance for the sediments [Slabunov et al., 2017a]. The foliated rocks of the Girar metasedimentary belt are overlain by gently dipping non-deformed Paleoproterozoic (ca. 2000-1800 Ma) rocks of the Bijawar Group [Saha and Mazumder, 2012]. This is indirect evidence for older, most probably Archean age for quartzite and BIF rocks of the Girar belt. Field observations evidence that Archean Ikauna peridotite-gabbro-diorite layered intrusive rocks, the pink granite and the less exposed TTG that occur north of the Girar metasedimentary belt are demarcated by a tectonic boundary [Farooqui and Singh, 2006; Slabunov et al., 2017a, 2018b].

Available data for supracrustal rocks of the Bundelkhand Craton are consistent enough to suppose that the Central Bundelkhand Greenstone Complex is a collage of at least two assemblages. Ca. $3.4 \mathrm{Ga}$ amphibolites [Singh et al., 2019a], associated with TTG gneisses on the southern side of the Babina belt, also seem to be part of the complex. However, this issue, tentatively interpreted as an independent event, should be studied in more detail. The early assemblage of the Central Bundelkhand Greenstone Complex was formed in the Mesoarchean, as indicated by the age of felsic volcanics $(2810 \pm 13 \mathrm{Ma})$. The formation of the basic-ultrabasic constituent of this assemblage, which comprises boninite-like varieties [Malviya et al., 2006], is attributed to subduction processes in the oceanic island-arc system (Fig. 3). This volcanism is followed by island-arc dacitic-rhyolitic volcanism. The 2810 Ma felsic volcanics are contaminated by older crustal material, as they contain $3.2 \mathrm{Ga}$ xenogenic zircons. This evidence suggests the emergence of an old crust fragment at the base 


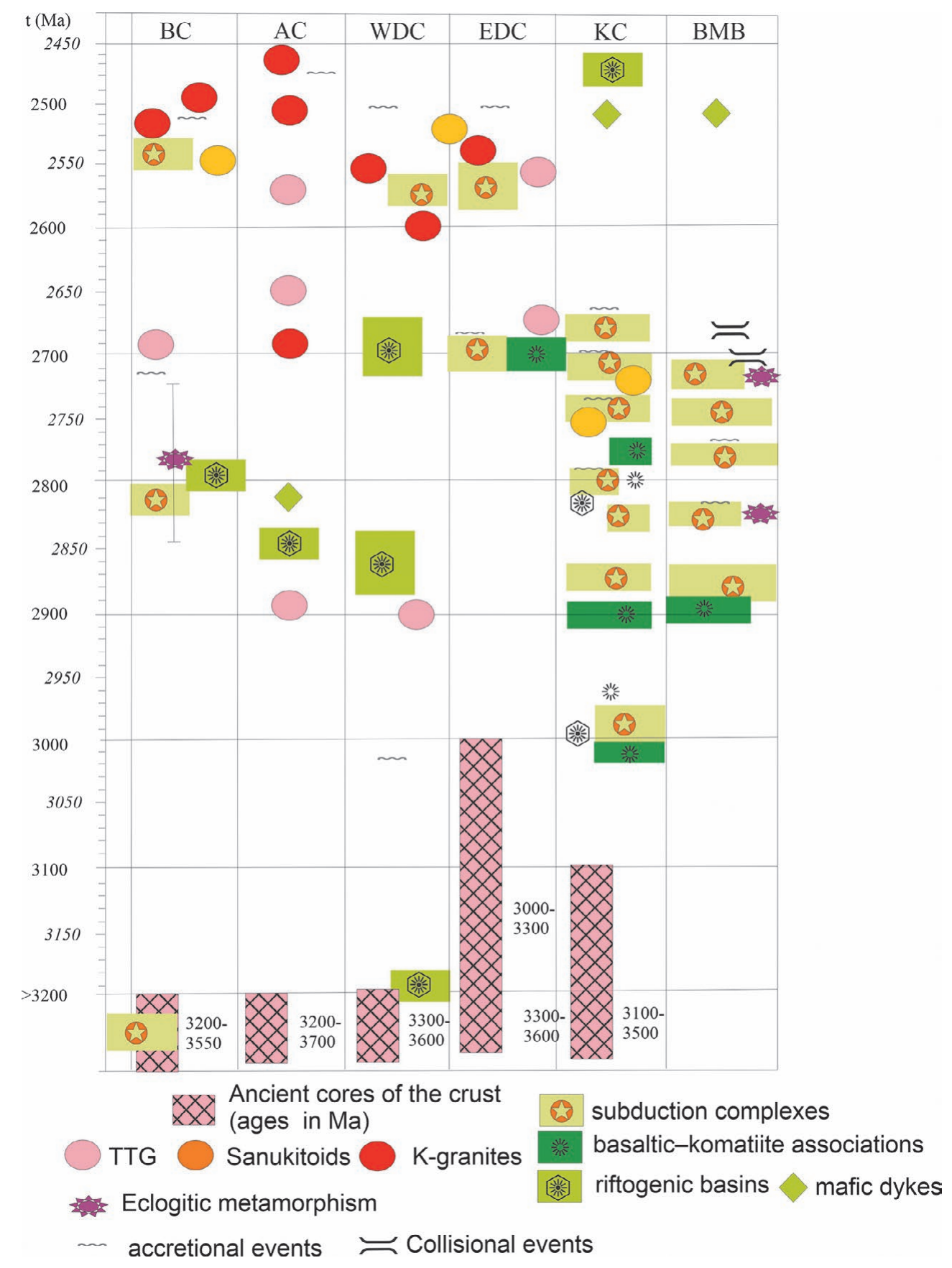

Fig. 3. The scheme of correlation of Archean geodynamic processes in the Bundelkhand $(B C)$, Western Dharwar (WDC), Eastern Dharwar (EDC), Aravalli (AC), Karelian (KC) Cratons and the Belomorian Mobile Belt (BMB) [modified after: Slabunov et al., 2006, 2017c; Slabunov, 2008; Slabunov and Singh, 2018, 2019a]

of the island-arc. This could be a microcontinent similar in composition to 3.6-3.2 Ga TTG complexes in the northern part of the Bundelkhand Craton [Mondal et al., 2002; Kaur et al., 2014; Saha et al., 2016], which approached the subduction zone and became part of a supra-subduction zone.

BIFs developed in the second-stage island-arc system in the basins. The BIFs of the Mauranipur belt formed in a back-arc basin and BIFs of the Babina belt occur in a fore-arc basin. Archean $(\sim 2780 \pm 60 \mathrm{Ma})$ eclogite-facies metamorphism and island-arc dacitic-rhyolitic volcanism $(\sim 2810 \pm 13 \mathrm{Ma})$ have relatively similar ages (within analytical uncertainty). This fact is an important argument in favour of the subductional nature of the early assemblage of the Central Bundelkhand Greenstone Complex [Slabunov et al., 2018a]. 
At about 2.7 Ga, the arc complex accreted to the southern continental block (Fig. 3). This event is marked by the formation of thrust faults and $2687 \pm 17 \mathrm{Ma}$ metamorphic processes, as indicated by the Mauranipur belt [Slabunov and Singh, 2017] and $2730 \pm 33 \mathrm{Ma}$ processes in the Babina belt [Saha et al., 2011]. The youngest $(2669.3 \pm 7.4 \mathrm{Ma})$ TTG formed here at that time as well [Verma et al., 2016], and TTG rocks of similar age $(2684 \pm 8 \mathrm{Ma})$ are also recognized in the Western Dharwar Craton [Dey et al., 2017].

Important events in the crustal evolution of the Bundelkhand Craton took place in the Neoarchean (Fig. 3), when the southern continental block was affected by a mantle plume responsible for the formation of a sedimentary basin, in which the quartzites and BIFs of the South Bundelkhand schist (metasedimentary) complex were formed [Singh and Slabunov, 2016, Slabunov et al., 2017a].

A new stage in the subduction processes began at 2.56-2.54 Ga. A spreading zone, which separated these blocks, seems to have existed in the ocean. However, the rate of its opening was slower than the rate of subduction at the periphery. At the southern margin of the northern block (it is the Babina belt in the modern coordinate system) subduction occurred in an active continental margin regime, as indicated by Neoarchean (2542 Ma [Singh and Slabunov, 2015a]) felsic volcanics in the Babina belt and a sanukitoid massif of similar age (2560-2559 Ma [Joshi et al., 2017]). At the northern flank of the southern continental block this stage is marked by Neoarchean (2557 Ma) dacites in the Mauranipur belt and a sanukitoid massif [Joshi et al., 2017]. The closure of the ocean and an accretion stage in the evolution of the greenstones took place at about $2.53 \mathrm{Ga}$, after the $2542 \mathrm{Ma}$ felsic volcanics and prior to the formation of the earliest 2531 Ma post-kinematic granites [Verma et al., 2016; Singh et al., 2020]. At this stage, its Meso- and Neoarchean constituents are combined to form one greenstone complex. The melting of large volumes of granitoids in the period $2.53-2.51 \mathrm{Ga}$ is associated with post-accretionary processes in the crust. The craton is stabilized at around $2.5 \mathrm{Ga}$.

\section{Geology and crustal evolution of the Aravalli Craton}

The Paleoproterozoic Aravalli Craton is the northernmost fragment of the Indian Shield (Figs. 1 and 2, b) [Ramakrishnan and Vaidyanadhan, 2010; Roy and Purohit, 2018]. It is probable that rocks from the Aravalli and Bundelkhand Cratons are found in Lesser Himalaya too [Mukherjee et al., 2019; Mishra et al., 2019]. All Precambrian complexes in NW India, such as the Archean Mewar gneiss complex, the Paleoproterozoic Aravalli Fold Belt, the Mesoproterozoic Delhi Fold Belt and Neoproterozoic Basins [Ramakrishnan and Vaidyanadhan, 2010], are often considered as its constituents. It is separated from the Bundelkhand Craton by the Paleo-Mesoproterozoic Vindhyan basin [Saha and Mazumder, 2012].

Archean rocks are exposed as several outcrops, 100 * 30-60 km in size, among the Paleoproterozoic (2.15-2.0 Ga) rocks of the Aravalli Supergroup (Fig. 2, b) [Roy and Purohit, 2018]. The latter rest with angular unconformity, occasionally with polymict conglomerates at the base of the sequence, on basement rocks [Roy et al., 1980]. Archean rocks are represented by migmatized TTG granitoids (known as the Banded Gneissic Complex (BGC)), fragments of greenstone complexes and granites [Ramakrishnan and Vaidyanadhan, 2010; Roy and Purohit, 2018; Kaur et al., 2019].

BGC rocks are biotite $( \pm$ muscovite, garnet and amphibole) gneisses with the petrogeochemical characteristics of TTG granitoids. BGC granitoids are dated at $3307 \pm 65 \mathrm{Ma}$ (Sm-Nd isochron [Gopalan et al., 1990]), $3312 \pm 7 \mathrm{Ma}$ and ca. $3281 \pm 3 \mathrm{Ma}$ (Zr, SIMS [Wiedenbeck and Goswami, 1994; Kaur et al., 2019]). Furthermore, Proterozoic sediments were shown to contain detrital zircons; their $\mathrm{Lu}-\mathrm{Hf}$ isotope system indicates the existence of ca $3.72 \mathrm{Ga}$ continental crust [Kaur et al., 2013]. Younger TTG granitoids aged $2885 \pm 5 \mathrm{Ma}$ [Roy and Kröner, 1996] and 2563-2548 Ma [Kaur et al., 2019] were also revealed in the region. They suggest the existence of a Mesoarchean episode in the formation of the continental crust. It should be noted also that $2830 \mathrm{Ma}$ gneisses have been described from the protolith of the Paleoproterozoic Sandmata granulite complex (Fig. 2, b) [Ramakrishnan and Vaidyanadhan, 2010].

Fragments of greenstone complexes occur among BGC (e. g., the Rakhiawal greenstone belt) as clusters of amphibolite, quartzite and ultramafic bodies, as well as marble, calc-silicate rocks, BIF, mica schist and barite [Roy and Jakhar, 2002; Roy and Purohit, 2018]. The greenstone belts have not been dated, but $2828 \pm 46$ Ma orthoamphibolites (metamorphosed dykes) occur in the Mavli area (Sm-Nd isochron [Gopalan et al., 1990]). The metadykes cut quartzites, which are a fragment of the greenstone belt and can thus be used to date the upper age boundary of the greenstone belts.

The 2660-2640 Ma magmatic events were recognized in BGC of the Aravalli Craton [Kaur et al., 2019]. Granodiorite-granite-leucogranite and pink K-rich granite have been dated at $2562 \pm 6$, $2532 \pm 5,2505 \pm 3,2450 \pm 8$ Ma [Wiedenbeck et al., 1996], among granites of the Aravalli Craton. 
The granites are interpreted as having been derived by melting of basement rocks during accretion-collision processes.

\section{Geology and crustal evolution of the Western and Eastern Dharwar Cratons}

The Dharwar Craton has been subdivided into two cratons: Western and Eastern, based on their evolution patterns and crustal structures (Fig. 1). Each of them is 3-4 times the size of the Bundelkhand Craton (Fig. 2, c).

The Western Dharwar Craton consists of mainly Paleoarchean (3.36-3.2 Ga) TTG gneisses (Peninsular gneisses). But there are older detrital zircons (3.58 Ga) in quartzites in the Dharwar Group of rocks. Three generations of greenstone complexes (Sargur, Bababudan and Chitradurga) and several granitoid massifs are reported from the Western Dharwar Craton [Jayanada et al., 2013; Radhakrishna, Ramakrishnan, 1990]. The Sargur greenstone belt is composed of mafic-ultamafic rocks (metabasalts, komatiites and their intrusive comagmates and metaanorthosites), which often predominate, and metasediments (kyanite/ sillimanite-staurolite-biotite gneisses, quartzites, BIF, local marble, calc-silicate rocks, bedded barite); with limited exposures of felsic volcanics. The age of the complex is estimated at $3.1-3.3 \mathrm{Ga}$, based on the $\mathrm{Sm}$ - Nd whole-rock isochron age of komatiites at $3352 \pm 110 \mathrm{Ma}$ [Jayananda et al., 2008] and the U-Pb age of zircon from felsic volcanics at $3298 \pm 7$ Ma [Peucat et al., 1995]. It forms small greenstone belts dominated by mafic-ultramafics (e. g. Ghatti Hosahalli, Krishnarajapet and Nagamangala) and those with abundant sediments (e. g. Sargur and Hole Narasipura). The Sargur greenstone complex was formed presumably in both rift-related structures on an early continental crust (3.58-3.23 Ga zircons in quartzites have been found, suggesting the existence of an older crust) and an oceanic plateau-type setting. The occurrence of $3.2 \mathrm{Ga}$ TTGs in the region suggests subduction processes of that age.

A second generation of greenstone complexes in the Western Dharwar Craton is the Meso-Neoarchean Bababudan Group at the base of the Dharwar Supergroup in Bababudan, Chitradurga schist belts (Fig. 2, c). The base of the Bababudan Group sequence consists of cross-bedded quartz conglomerates with ripple marks (Kalasapura Formation). These sediments rest with angular unconformity on Peninsular gneisses and Sargur Group rocks. In addition to quartz conglomerates, the Bababudan Group comprises phyllites and BIF. Mafic (metabasalts and gabbroic rocks) and ultramafic bodies seem to occur among them as sills.
Felsic volcanics, occurring as part of the Santaveri Formation, are scarce. The mafics-ultramafics are dated at 2.9-2.85 Ga ( $\mathrm{Sm}$ - Nd whole rock isochron ages are $2911 \pm 49$ and $2848 \pm 70 \mathrm{Ma}$ [Kumar et al., 1996]). The formation of the Bababudan greenstone complex was associated with plume activity and took place in an intracontinental basin.

A third greenstone/schist complex of the craton corresponds with the Chitradurga Group of the Dharwar Supergroup, which makes up the largest exposures around Shimoga and Chitradurga area (Fig. 2, c). This Group consists predominantly of sediments (quartz and polymictic conglomerates containing TTG and Bababudan Group rock fragments, chert-phyllite, manganese and iron formation and stromatolitic carbonates) with pillow basalt and lesser felsic volcanic intercalations. The complex is dated at $2.75-2.58 \mathrm{Ga}$ as the $\mathrm{Sm}-\mathrm{Nd}$ whole rock isochron age is $2747 \pm 15$ Ma [Kumar et al., 1996]; the U-Pb age of zircon from the felsic volcanic is $2677 \pm 2$ to $2576 \pm 20$ $\mathrm{Ma}$ [Jayananda et al., 2013]. The sedimentation basin of the Chitradurga Group [Hokada et al., 2013] seems to have been controlled by mantle plume activity.

The Eastern Dharwar Craton is separated from the Western Dharwar Craton by a large fault, the Chitradurga shear zone, and differs from the latter in deep geophysical structure (a thinner earth crust [Gupta et al., 2003]) and the compositions and ages of Archean granitoid and greenstone complexes [Ram Mohan et al., 2013; Yang and Santosh, 2015]. The Eastern and Western Dharwar Cratons consist chiefly of commonly migmatized TTG granitoids, but, in contrast to the Eastern Dharwar Craton, they are dominated by $2.7-2.55 \mathrm{Ga}$ rocks with minor fragments of 3.0-3.38 Ga crust [Jayananda et al., 2013 and references therein]. Moreover, the contribution of older crustal material to the granitoid composition decreases markedly ( $\mathrm{Nd} \mathrm{T}_{\mathrm{DM}}$ up to 2.8-3.0 Ga in the eastern part [Dey, 2013], but $2.56-2.5 \mathrm{Ga}$ juvenile $(\varepsilon \mathrm{Nd}=+3.3)$ calc-alkaline to potassic granitoids are widespread here). The 2.51-2.53 Ga, N-S-trending sanukitoid-like Closepet Granite batholiths occur in the western part of the Eastern Dharwar Craton, which crosscuts the entire craton (Fig. 2, c).

The greenstone belts of the Eastern Dharwar Craton are small, narrow, $\mathrm{N}-\mathrm{S}$ and NW-SE trending linear structures, e. g. Kolar, Hutti, Kushtagi etc. They consist mainly of metabasalts (often pillowed) associated with komatiites and BIF; felsic volcanics associated with greywacke and polymictic conglomerates (Kolar GB) are more common; and metasediments occurring as schists are less common. An early association (beginning proba- 
bly at $2.75 \mathrm{Ga}$, but mainly arising at ca. $2.7 \mathrm{Ga}$ ) of basalts and komatiites was formed in an oceanic setting under the influence of plumes, i. e. oceanic plateaus, but this stage was also terminated by subduction processes (Sangur GB). However, the main episode in the subduction processes, which gave rise to continental crust, occurred at 2.58-2.52 Ga, when felsic volcanics and various granitoids (including sanukitoids) originated. Ca. $2.5 \mathrm{Ga}$ granulite-facies metamorphism, widespread in the southern part of the Eastern and Western Dharwar Cratons, was associated with accretion-collision processes.

\section{Discussion}

Studies on each of the cratons (Western and Eastern Dharwar, Bundelkhand and Aravalli Cratons of the Indian Shield) have evaluated, revealing craton-specific structural and evolutional characteristics. First of all, it should be noted that the Bundelkhand and Aravalli Cratons are much smaller than the Western and Eastern Dharwar Cratons (Figs. 1 and 2) However, they comprise TTG, greenstone/ schist and granitoids complexes which are the most typical of Archean cratons. The cores of all the cratons commonly consist of Paleoarchean TTG.

The oldest (3.6-3.2 Ga) TTG occur in the central Bundelkhand Craton, but they seem to have been more common. The ca. $3.43 \mathrm{Ga}$ mafic-ultramafic complexes seem to have been formed together with TTG granitoids in a subduction geodynamic setting. TTG gneisses of the Aravalli Craton are also dated at ca. 3.3-3.2 Ga, but an older (pre-3.7 Ga) protolith is assumed to have existed. The Western Dharwar Craton is dominated by 3.36-3.2 Ga TTG, but they had probably comprised even older (up to $3.58 \mathrm{Ga}$ ) constituents, which have survived only as detrital zircons in sedimentary rocks. It should also be noted that the formation of the Paleoarchean (3.3-3.2 Ga) Sargur greenstone complex is similar in age to the TTG, like that in the Bundelkhand Craton. The Eastern Dharwar Craton displays a somewhat different distribution and age of old TTG: fragments of 3.3-3.0 Ga TTG occur here as part of migmatized gneisses in the western part, while its eastern portion consists of juvenile Neoarchean (2.7-2.55 Ga) granitoids, including TTG (Fig. 3).

The Meso-Neoarchean (2.9-2.6 Ga) evolution of the Western Dharwar Craton was affected by mantle plumes. As a result, intraplate sedimentary basins, exhibiting bimodal magmatism, were derived. The intrusion of $2.61 \mathrm{Ga}$ potassium-granites stabilized the craton. The processes occurring in the Eastern Dharwar Craton were entirely different i. e. the formation of a juvenile continental crust took place here mainly in Neoarchean time, beginning at 2.75-2.7 Ga, but dominantly during 2.58-2.54 Ga. The leading role was played by subduction processes, which were terminated by the accretion of the newly-formed crust to the Western Dharwar Craton, which had stabilized earlier.

The Mesoarchean crustal evolution of the Aravalli Craton is poorly described, but its greenstone complexes (quartzites, amphibolites and ultramafics) suggest their formation in an intraplate setting.

The crustal evolution of the Bundelkhand Craton is quite different from that described above. One of the essential differences is that in Mesoarchean time (ca. 2.81 Ga) a new continental crust was formed during subduction here and in the Karelian Craton [Slabunov et al., 2006; Slabunov and Singh, 2011], but it was not transformed by plumes as for the Western Dharwar Craton.

The Neoarchean evolution of the central Bundelkhand Craton differed from that of the southern Bundelkhand Craton. The former was an area where the ocean, dividing the northern and southern terrains, was closing. Subduction processes were active here at ca. $2.7 \mathrm{Ga}$, but were the most vigorous at 2.56-2.54 Ga, and were terminated by accretion-collision events and the formation of 2.53-2.5 Ga potassium-granites. Crustal formation in the Central Bundelkhand Terrane is similar in time and geodynamic pattern to the Eastern Dharwar Craton, but there are some essential differences. Subduction processes in the Eastern Dharwar Craton occurred in an island-arc regime and those in the Bundelkhand Craton in an active continent margin regime. The earth crust of the Southern Bundelkhand Terrane, where presumably Neoarchean layered intrusions and a sedimentary basin (Girar greenstone/schist belt) were revealed, was formed in a different manner. The effect of a mantle plume is considered in the Southern Bundelkhand Terrane and in the Western Dharwar Craton during this time.

In the late Neoarchean (ca. 2.5 Ga) the Western and Eastern Dharwar Cratons were involved as one structure in an accretion-collision process, which gave rise to southern Dharwar Craton granulites.

Thus, correlation of the Meso-Neoarchean crustal evolution of the Bundelkhand, Aravalli, Western and Eastern Dharwar Cratons shows that geodynamic mechanisms, similar to modern plate-tectonic and mantle-plume, were active in that period (Fig. 3). Each of the cratons displays its own crustal formation pattern. It seems that in Archean time the Bundelkhand, the Aravalli, the Western and Eastern Dharwar Cratons were the various parts of the Kenorland Supercontinent (Fig. 4). 

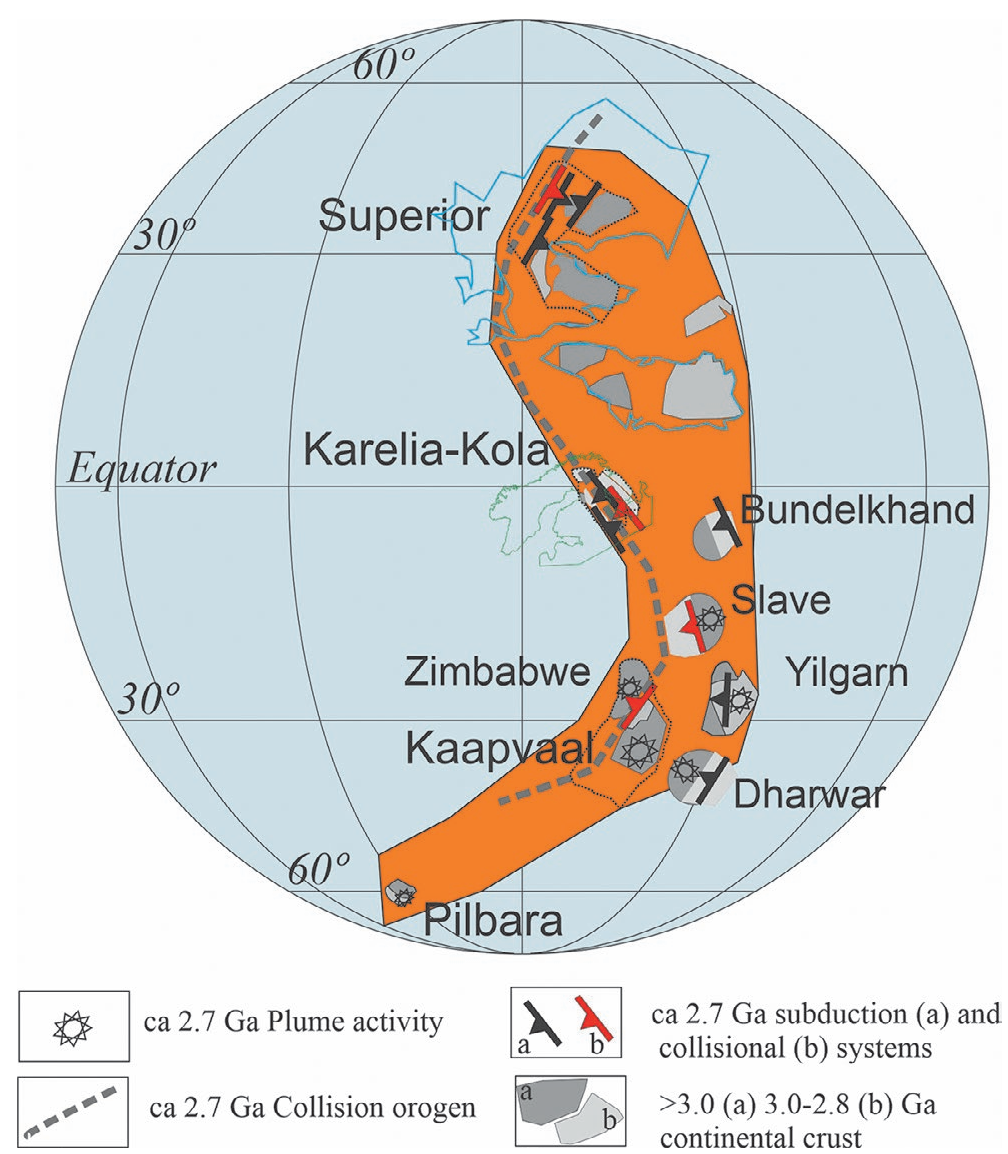

ca 2.7 Ga subduction (a) and collisional (b) systems

$>3.0$ (a) $3.0-2.8$ (b) Ga continental crust

Fig. 4. A reconstruction of the Kenorland supercontinent in the Neoarchean (ca. 2.7 Ga) [modified after: Lubnina and Slabunov, 2017] and the Bundelkhand, Dharwar and Aravalli Cratons locations

In accordance with the paleotectonic reconstruction of the Kenorland Supercontinent (Fig. 4), based on geological and paleomagnetic data, it is presumed to be crescentiform [Lubnina and Slabunov, 2009, 2011, 2017; Slabunov and Lubnina, 2016 and references therein]. In the northern part of this supercontinent the active growth of the continental crust in the Meso-Neoarchean period (2.9-2.7 Ga) was provoked by subduction-accretion processes, while in its southern part plume processes and subduction processes played an important role [Lubnina and Slabunov, 2011]. This evidence suggests and revealed that Mesoarchean subduction-accretion processes in the Bundelkhand Craton were similar to those characteristic of the Karelian Craton and of the Superior Province, in the northern half of the forming supercontinent. In the Mesoarchean, the Western Dharwar Craton was dominated by plume processes, and it was not until the Neoarchean (from $2.7 \mathrm{Ga}$ onwards) that continental crust began to form again there, and especially in the Eastern Dharwar Craton during subduction-accretion processes. In the Mesoarchean, these continental blocks seem to have been in the southern part of the forming supercontinent. In the Neoarchean (ca. 2.6 Ga), when the core of the supercontinent was formed, the crust seems to have continued to grow in its southern part until 2.5 Ga during subduction and accretion processes in the Bundelkhand, Aravalli and Western and Eastern Dharwar Cratons (Fig. 4).

The work was supported by DST-RFBR (INT) $R U S / R F B R / P-279$ and RFBR-17-55-45005 IND) grants, it continues under MOU between Bundelkhand University, Jhansi, India and the Institute of Geology, Karelian Research Centre, RAS, Petrozavodsk, Russia, and is a contribution to Project AAAA-A18-118020290085-4.

\section{Reference}

Basu A. K. Geology of parts of Bundelkhand granite massif, Central India. Rec. Geol. Surv. India. 1986. Vol. 117. P. 61-124.

Chadwick B., Vasudev V. N., Hegde G. V. The Dharwar Craton, southern India, interpreted as the result of late Archaean oblique convergence. Precambrian Res. 2000. Vol. 99. P. 91-101.

Chardon D., JayanandaM., ChettyT.R.K., Peucat J.-J. Precambrian continental strain and shear zone 
patterns: South Indian case. J. Geophys. Res. 2008. Vol. 113. B08402. doi: 10.1029/2007JB005299

Dey S. Evolution of the Archaean crust in the Dharwar Craton: The $\mathrm{Nd}$ isotope record. Precambrian Res. 2013. Vol. 227. P. 227-246.

Dey S., Halla J., Kurhila M., Nandy J., Heilimo E., PalS. Geochronology of Neoarchaean granitoids of the NW eastern Dharwar Craton: implications for crust formation. In: Halla J., Whitehouse M. J., Ahmad T., Bagai Z. (Eds). Crust - Mantle Interactions and Granitoid Diversification: Insights from Archaean Cratons. Geol. Society, London. Special Publications 449. 2017. P. 89-121. doi: 10.1144/SP449.9

Farooqui S. A., SinghA. K. Platinum mineralization in Ikauna Area, Lalitpur District, Uttar Pradesh. J. Geol. Soc. India. 2006. Vol. 68. P. 582-584.

Gopalan K., Macdaugall J. D., Roy A. B., MuraIi A. V. Sm-Nd evidence for 3.3 Ga old rock in Rajasthan, north-western India. Precambrian Res. 1990. Vol. 48. P. 287-297.

Gupta S., Rai S. S., Prakasam K. S., Srinagesh D., Bansal B. K., ChadhaR. K., Preistley K., Gaur V. K. The nature of the crust in southern India: implications for Precambrian crustal evolution. Geophys. Res. Lett. 2003. Vol. 30. P. 419.

Hokada T., Horie K., Satish-Kumar M., Ueno Y., Nasheeth A., Mishima K., Shiraishi K. An appraisal of Archaean supracrustal sequences in Chitradurga Schist Belt, Western Dharwar Craton, Southern India. Precambrian Res. 2013. Vol. 227. P. 99-119.

Jayananda M., PeucatJ.-J., Chardon D., Krishna Rao B., Fanning C. M., Corfu F. Neoarchean greenstone volcanism and continental growth, Dharwar craton, southern India: Constraints from SIMS U-Pb zircon geochronology and $\mathrm{Nd}$ isotopes. Precambrian Res. 2013. Vol. 227. P. 55-76.

Jayananda M., Kano T., Peucat J. J., Channabasappa S. 3.35 Ga komatiite volcanism in the western Dharwar Craton, southern India: constraints from $\mathrm{Nd}$ isotopes and whole rock geochemistry. Precambrian Res. 2008. Vol. 162. P. $160-179$.

Jayananda M., Chardon D., Peucat J.-J., Tushipokla, Fanning C. M. Paleo- to Mesoarchean TTG accretion and continental growth in the western Dharwar Craton, Southern India: Constraints from SHRIMP U-Pb zircon geochronology, whole-rock geochemistry and $\mathrm{Nd}-\mathrm{Sr}$ isotopes. Precambrian Res. 2015. Vol. 268. P. 295-322.

Joshi K. B., Bhattacharjee J., Rai G., Halla J., Kurhilla M., Heilimo E., Ahmad T., Whitehouse M. The diversification of granitoids and plate tectonic implications at the Archaean - Proterozoic boundary in the Bundelkhand Craton, Central India. In: Halla J., Whitehouse M. J., Ahmad T., Bagai Z. (Eds). Crust - Mantle Interactions and Granitoid Diversification: Insights from Archaean Cratons. Geol. Society, London, Special Publications, 449. 2017. P. 123-157. doi: 10.1144/SP449.8

Kaur P., Zeh A., Chaudhri N., Gerdes A., Okrusch M. Nature of magmatism and sedimentation at a Columbia active margin: Insights from combined $\mathrm{U}-\mathrm{Pb}$ and $\mathrm{Lu}-\mathrm{Hf}$ isotope data of detrital zircons from NW India. Gondwana Res. 2013. Vol. 23. P. 1040-1052.

Kaur P., ZehA., ChaudhriN. Characterisation and $\mathrm{U}-\mathrm{Pb}-\mathrm{Hf}$ isotope record of the $3.55 \mathrm{Ga}$ felsic crust from the Bundelkhand Craton, northern India. Precambrian Res. 2014. Vol. 255. P. 236-244.

Kaur P., Zeh A., Chaudhri N., Eliyas N. Unravelling the record of Archaean crustal evolution of the Bundelkhand Craton, northern India using U-Pb zircon monazite ages, Lu-Hf isotope systematics, and wholerock geochemistry of granitoids. Precambrian Res. 2016. Vol. 281. P. 384-413.

Kaur P., Zeh A., Chaudhri N. Archean crustal evolution of the Aravalli Banded Gneissic Complex, NW India: Constraints from zircon $\mathrm{U}-\mathrm{Pb}$ ages, $\mathrm{Lu}-\mathrm{Hf}$ isotope systematics, and whole-rock geochemistry of granitoids. Precambrian Res. 2019. Vol. 327. P. 81-102.

Kumar A., Bhaskar Rao Y. J., Sivaraman T. V., Gopalan K. Sm-Nd ages of Archaean metavolcanic of the Dharwar Craton, South India. Precambrian Res. 1996. Vol. 80. P. 206-215.

Lubnina N. V., Slabunov A. I. Paleomagnetism in the Neoarchean Polyphase Panozero Intrusion in the Fennoscandian Shield. Moscow Univ. Geol. Bull. 2009. Vol. 64. P. 346-353.

Lubnina N. V., Slabunov A. I. Reconstruction of the Kenorland supercontinent in the Neoarchean based on paleomagnetic and geological data. Moscow Univ. Geol. Bull. 2011. Vol. 66(4). P. 242-249.

Lubnina N. V., SlabunovA.I. The Karelian Craton in the structure of the Kenorland supercontinent in the Neoarchean: New paleomagnetic and isotope geochronology data on granulites of the Onega Complex. Moscow Univ. Geol. Bull. 2017. Vol. 72(6). P. 377-390.

Mukherjee P. K., Jain A. K., Singhal S., Singha N. B. Singh S., Kumud K., Seth P., PatelR. C. U-Pb zircon ages and $\mathrm{Sm}-\mathrm{Nd}$ isotopic characteristics of the Lesser and Great Himalayan sequences, Uttarakhand Himalaya and their regional tectonic implications. Gondwana Res. 2019. Vol. 75. P. 282-297. doi: 10.1016/j.gr.2019.06.001

Mishra S., Singh V. K., Slabunov A. I., Nainwal H. C. Geochemistry and petrogenesis of Proterozoic granites of Garhwal Lesser Himalaya. The $9^{\text {th }}$ Hutton Symp. on the Origin of Granites and Related Rocks. Nanjing, China. 2019. P. 135-136.

Malviya V. P., Arima M., Pati J. K., Kaneko Y. Petrology and geochemistry of metamorphosed basaltic pillow lava and basaltic komatiite in the Mauranipur area: subduction related volcanism in the Archean Bundelkhand Craton, Central India. J. Mineral. Petrol. Sci. 2006 Vol. 101. P. 199-217.

Mondal M. E. A., Goswami J. N., Deomurari M. P., Sharma K. K. Ion microprobe $207 \mathrm{~Pb} / 206 / \mathrm{Pb}$ ages of zircon from the Bundelkhand massif, northern India: implication for crustal evolution of the Bundelkhand - Aravalli protocontinent. Precambrian Res. 2002. Vol. 117. P. 85-100.

Naqvi S. M., Rogers J. J.W. Precambrian geology of India: Oxford monographs on geology and geophysics 6. Oxford University. 1987. 223 p.

Nasipuri P., Saha L., Hangqiang X., Pati J. K., Manavan Satyanaryanan M., Sarkar S., Bhandari A., Gaur Y. Paleoarchean crustal evolution of the Bundelkhand Craton, North Central India. In: van Kranendonk M. J., Bennett V. C., Hoffmann J. E. (eds). Earth's Oldest Rocks. $2^{\text {nd }}$ Edition. Elsevier, 2019. P. 793-817.

Pati J. K., Patel S. C., Pruseth K. L., Malviya V. P., Arima M., Raju S., Pati P., Prakash K. Geology and geo- 
chemistry of giant quartz veins from the Bundelkhand Craton, Central India and their implications. J. Earth Syst. Sci. 2007. Vol. 116. P. 497-510.

Peucat J. J., Bouhallier H., Fanning C. M., Jayananda $M$. Age of the Holenarsipur Greenstone Belt, relationships with the surrounding gneisses (Karnataka, South India). J. Geol. 1995. Vol. 103. P. 701-710.

Pradhan V. R., MeertJ. G., PanditM. K., Kamenov G., Mondal M. E. A. Paleomagnetic and geochronological studies of the mafic dyke swarms of the Bundelkhand Craton, Central India: Implications for the tectonic evolution and paleogeographic reconstructions. Precambrian Res. 2012. Vol. 198-199. P. 51-76.

Ram Mohan M., PierceyS. J., Kamber B. S., SarmaD.S. Subduction related tectonic evolution of the Neoarchean eastern Dharwar Craton, southern India: New geochemical and isotopic constraints. Precambrian Res. 2013. Vol. 227. P. 204-226.

Radhakrishna B. P., Ramakrishnan M. (eds). Archaean Greenstone Belts of South India. Geol. Society of India, Bangalore, 1990. 497 p.

Ramakrishnan M., Vaidyanadhan R. Geology of India. Vol. 1. Geol. Society of India, Bangalore, 2010. $556 \mathrm{p}$.

Roy A. B., Jakhar S. R. Geology of Rajasthan: Precambrian to Recent. Sci. Publishers (India), Jodhpur. 2002. $421 \mathrm{p}$.

Roy A. B., Kröner A. Single zircon evaporation ages constraining the growth of the Archaean Aravalli craton, northwestern Indian Shield. Geol. Magazine. 1996. Vol. 133. P. 333-342.

Roy A. B., Nagori D., Golani P. R., Dhakar S. P., Choudhuri $R$. Structural geometry of the phosphorite bearing Aravalli rocks around Jhamarkotra Mines area, Udaipur dist., Rajasthan. Indian J. Earth Sci. 1980. Vol. 7. P. 191-202.

Roy A. B., Purohit R. Indian Shield: Precambrian evolution and Phanerozoic reconstitution. Elsevier, 2018. $375 \mathrm{p}$.

Saha D., Mazumder R. An overview of the Palaeoproterozoic geology of Peninsular India, and key stratigraphic and tectonic issues. In: Mazumder R., Saha D. (eds). Palaeoproterozoic of India. Special Publications, 365. Geol. Society, London. 2012. P. 5-29. doi: 10.1144/ SP365.2

Saha L., Frei D., Gerdes A., Pati J. K., Sarkar S., Patole V., Bhandari A., Nasipuri P. Crustal geodynamics from the Archaean Bundelkhand Craton, India: constraints from zircon U-Pb - Hf isotope studies. Geol. Magazine. 2016. Vol. 153. P. 79-192.

Saha L., Pant N.C., PatiJ.K., UpadhyayD., BerndtJ., Bhattacharya A., Satynarayanan M. Neoarchean high-pressure margarite-phengitic muscovite-chlorite corona mantled corundum in quartz-free high-Mg, Al phlogopite-chlorite schists from the Bundelkhand Craton, north Central India. Contrib. Mineral. Petrol. 2011. Vol. 161. P. 511-530.

Sibelev O. S., Slabunov A. I., Mishra S., Singh V. K. Metamorphism of the Central Bundelkhand greenstone complex of the Bundelkhand Craton, Indian Shield. Trans. of A. Fersman Sci. Session of Geol. Inst. KRC RAS. 2019. No. 16. P. 512-516. doi: 10.31241/FNS. 2019.16.104
Singh V. K., SlabunovA. The Greenstone Belts of the Bundelkhand Craton, Central India: new geochronological data and geodynamic setting. In: Singh V. K., Chandra R. (eds.). International Association for Gondwana research Conference Series No. 16, $3^{\text {rd }}$ Int. conf Precambrian Continental Growth and Tectonism, Jhansi, India. 2013. P. 170-171.

Singh V. K., Slabunov A. The Central Bundelkhand Archaean greenstone complex, Bundelkhand Craton, Central India: geology, composition, and geochronology of supracrustal rocks. Int. Geol. Rev. 2015a Vol. 57(11-12). P. 1349-1364.

Singh V. K., Slabunov A. Geochemical characteristics of banded iron formation and metavolcanics of Babina Greenstone Belt of the Bundelkhand Craton, Central India. J. Economic Geol. and Geo Resource Management. 2015b. Vol. 10. P. 63-74.

Singh V. K., Slabunov A. Two types of Archaean supracrustal belts in the Bundelkhand Craton, India: geology, geochemistry, age, and implication for craton crustal evolution. J. Geol. Soc. India. 2016. Vol. 88. P. 539-548.

Singh P. K., Verma S. K., Moreno J. A., Singh V. K., Malviya P. K., Oliveira E. P., Mishra S., Arima M. Geochemistry and $\mathrm{Sm}-\mathrm{Nd}$ isotope systematics of metabasalts from the Babina and Mauranipur Greenstone Belts, Bundelkhand Craton: Implications for tectonic setting and Paleoarchean mantle evolution. Lithos. 2019a. Vol. 330-331. P. 90-107. doi: 10.1016/j.lithos. 2019.02.010

Singh P. K., Verma S. K., Singh V. K., Moreno J. A., Oliveira E. P., Mehta P. Geochemistry and petrogenesis of sanukitoids and high-K anatectic granites from the Bundelkhand Craton: Implications for the late-Archean crustal evolution. J. Asian Earth Sci. 2019b. Vol. 174. P. 263-282. doi: 10.1016/j.jseaes.2018.12.013

Singh V. K., Slabunov A. I., Singh P. K. Paleoproterozoic Giant quartz veins and rift-related basins of the Bundelkhand Craton, northern India: relationship and geodynamic consequences. Recent Trends in Earth Sci. Res. At: Department of Geol., Banaras Hindu Univ., Varanasi. 2019c. P. 81.

Singh V. K., Verma S. K., Singh P. K., Slabunov A. I., Chaudhary N., Mishra S. Archean crustal evolution of the Bundelkhand Craton: Evidence from granitoid magmatism In.: Archean Granitoids of India: Windows into Early Earth Tectonics. Special Publications 489. Geol. Society, London. 2020. doi: 10.1144/ SP489-2018-72

Slabunov A. I. Geology and geodynamics of the Archean mobile belts (example from the Belomorian province of the Fennoscandian Shield)). Petrozavodsk: KarRC RAS, 2008. 296 p. (In Russian).

SlabunovA. Comparison of the crustal evolution of the Fennoscandian, Southern African and Indian Shields in the Meso- to Neoarchean time and Kenorland supercontinent. In: Singh V. K., Chandra R. (eds.). International Association for Gondwana research Conference Series No. 16, $3^{\text {rd }}$ Int. conf. Precambrian Continental Growth and Tectonism, Jhansi, India. 2013. P. 173-175.

Slabunov A. I., Guo J., Balagansky V. V., Lubnina N. V., Zhang L. Early Precambrian Crustal evolution of the Belomorian and Trans-North China orogens and supercontinents reconstruction. Geodynamics 
and Tectonophysics. 2017c. Vol. 8. P. 569-572. doi: 10.5800/GT-2017-8-3-0293

Slabunov A. I., Lubnina N. V. Neoarchean supercontinent Kenorland: geological and paleomagnetic data. Proc. $35^{\text {th }}$ IGC. Cape Town, South Africa, Alexandria: Am. Geosci. Inst., 2016. P. 3751.

Slabunov A. I., Singh V. K. Archaean crustal evolution of the Fennoscandian and Bundelkhand Craton: prospective. In: Singh V. K., Chandra R. (eds.). Precambrian Continental Growth and Tectonism: Proceed. $2^{\text {nd }}$ int. conf. 2011. P. 3-12.

Slabunov A., Singh V.K. Central Bundelkhand greenstone complex of the Bundelkhand Craton, India: new geochronological data, a geodynamic setting, and the position of the Craton in the Kenorland supercontinent structure. In: Slabunov A. I., Svetov S. A., Baltibaev Sh. K. (eds.). Early Precambrian vs Modern Geodynamics. Extended Abstracts and Field Trips Guide. Petrozavodsk: KarRC RAS, 2017. P. 239-241.

SlabunovA., Singh V.K. Bundelkhand and Dharwar Cratons (Indian Shield): comparison of crustal evolution in the Archean time. Arch \& Anthropol Open Acc 3 (suppl-2). 2018. P. 42-48. doi: 10.31031/AAOA. 2018.03.000556

Slabunov A. I., Singh V. K. Meso-Neoarchaean crustal evolution of the Bundelkhand Craton, Indian Shield: new data from greenstone belts. Int. Geol. Rev. 2019a. Vol. 61. P. 1409-1428. doi: 10.1080/00206814.2018. 1512906

SlabunovA., Singh V.K. The new tectonic division of the Bundelkhand Craton Indian Shield. Trans. of A. Fersman Sci. Session of Geol. Inst. KRC RAS. 2019b. No. 16. P. 521-524. doi: 10.31241/FNS. 2019.16.106

SlabunovA., Singh V.K. Giant quartz veins and rift-related basins as indicators of the Paleoproterozoic destruction of the earth crust of cratons in Northern India. Formation and evolution stages of the Proterozoic Earth Crust: stratigraphy, metamorphism, and geodynamics. Proceed. $6^{\text {th }}$ Russ. conf. on Precambrian geol. and geodynamics. St. Petersburg, Russia, 2019c. P. 213-215.

Slabunov A., Singh V. K., Joshi K. B., LiX. Paleoarchean zircons from quartzite of South Bundelkhand Supracrustal Complex: origin and implications for crustal evolution in Bundelkhand Craton, Central India. Current Science. 2017a. Vol. 112. P. 794-801.

\section{СВЕДЕНИЯ ОБ АВТОРАХ:}

\section{Слабунов Александр Иванович}

главный научный сотрудник, заведующий лаб. геологии и геодинамики докембрия, д. г.-м. н.

Институт геологии КарНЦ РАН,

Федеральный исследовательский центр

«Карельский научный центр РАН»

ул. Пушкинская, 11, Петрозаводск, Республика Карелия,

Россия, 185910

эл. почта: slabunov@krc.karelia.ru

тел.: (8142) 783630
Slabunov A. I., Singh V. K., Shchiptsov V. V., Lepekhina E. N., Kevlich V. I. A new Paleoproterozoic $(1.9-1.8 \mathrm{Ga})$ event in the crustal evolution of the Bundelkhand Craton, India: the results of (SHRIMP) Dating of zircons from giant quartz veins. In: Slabunov A. I., Svetov S. A., Baltibaev Sh. K. (eds.). Early Precambrian vs Modern Geodynamics. Extended Abs. and Field Trips Guide. Petrozavodsk: KarRC RAS, 2017b. P. 239-241.

Slabunov A. I., Singh V. K., Svetov S. A. Crustal evolution of the Bundelkhand Craton (Indian Shield) and Archean geodynamic processes. Problems in the tectonics and geodynamics of the Earth Crust and the mantle. Proceed. $1^{\text {st }}$ Tectonic Meeting. Vol II. Moscow, 2018a P. 193-196.

Slabunov A., Egorova S., Singh V. K., Svetov S., Kumar $S$. Archean mafic-ultramafic Ikauna layered intrusion, Bundelkhand Craton, India: petrography and geochemistry. Arch \& Anthropol Open Acc. 3 (suppl-2). 2018b. P. 49-55. doi: 10.31031/AAOA. 2018.03.000557

Slabunov A. I., Lobach-Zhuchenko S. B., Bibikova E. V., Sorjonen-WardP., Balagansky V. V., VolodichevO. I., ShchipanskyA.A., SvetovS. A., Chekulaev V. P., Arestova N. A., Stepanov V. S. The Archean nucleus of the Fennoscandian (Baltic) Shield. In. Gee D. G., Stephenson R. A. (eds). European Lithosphere Dynamics. Geol. Society, London, Memoirs. 2006. Vol. 32. P. 627-644.

Verma S. K., Verma S. P., Oliveira E. P., Singh V. K., More J. A. LA-SF-ICP-MS zircon U-Pb geochronology of granitic rocks from the central Bundelkhand greenstone complex, Bundelkhand craton, India. J. Asian Earth Sci. 2016. Vol. 118. P. 125-137.

Wiedenbeck M., Goswami J. N. An ion-probe single zircon ${ }^{207} \mathrm{~Pb} /{ }^{206} \mathrm{~Pb}$ age from Mewar Gneiss at Jhamarkotra, Rajasthan. Geochim. Cosmochim. Acta. 1994 Vol. 58. P. 2135-2141.

Wiedenbeck M., Goswami J. N., Roy A. B. Stabilization of the Aravalli Craton of the northwestern India at $2.5 \mathrm{Ga}$.: an ion-microprobe zircon study. Chem. Geol. 1996. Vol. 129. P. 325-340.

Yang Q.-Y., Santosh M. Zircon U-Pb geochronology and Lu-Hf isotopes from the Kolar Greenstone Belt, Dharwar Craton, India: Implications for crustal evolution in an ocean-trench-continent transect. J. Asian Earth Sci. 2015. Vol. 113(2). P. 797-811.

Received January 29, 2020

\section{CONTRIBUTORS:}

Slabunov, Alexander

Institute of Geology, Karelian Research Centre, Russian Academy of Sciences

11 Pushkinskaya St., 185910 Petrozavodsk, Karelia, Russia e-mail: slabunov@krc.karelia.ru tel.: (8142) 783630 
Сингх Винод Кумар

доцент, PhD

Бунделкхандский университет, геологический факультет

Джанси, Индия, 284128

эл. почта: vinodksingh@bujhansi.ac.in

тел.: +919415258237
Singh, Vinod

Department of Geology Bundelkhand University,

284128 Jhansi, India

e-mail: vinodksingh@bujhansi.ac.in

tel. +919415258237 